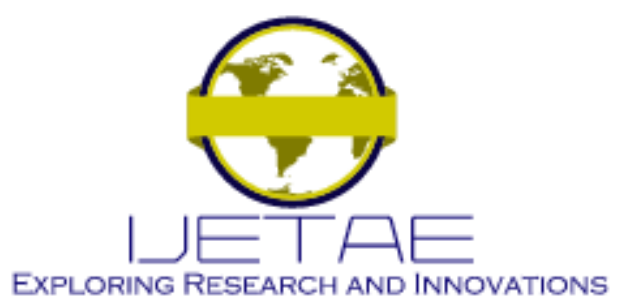

International Journal of Emerging Technology and Advanced Engineering

Website: www.ijetae.com (E-ISSN 2250-2459, Scopus Indexed, ISO 9001:2008 Certified Journal, Volume 11, Issue 09, September 2021)

\title{
Analysis of Factors Affecting the Loyalty of Indonesian Mobile Game Players and Its Impact on In-App Purchase Intention
}

\author{
Alek Maulana Muqarrabin ${ }^{1}$, Mts. Arief ${ }^{2}$, Idris Gautama ${ }^{3}$, Pantri Heriyati ${ }^{4}$
}

\begin{abstract}
Indonesian game creators contribute as little as $1 \%$ of the market share in Indonesia's expanding mobile gaming sector. This research examines the factors influencing mobile game players' loyalty in Indonesia and their influence on app purchase intention. The population in this study are online mobile game players in Indonesia, the data collection method used a questionnaire distributed to 404 mobile game players in Indonesia using a simple random sampling technique. In addition, this study uses the SEM-PLS analysis method. The study found that perceived value, game technology, subjective norms, and online community engagement have a substantial influence on loyalty and affect in-app purchase intention. Furthermore, perceived value directly impacts in-app purchase intent.
\end{abstract}

Keywords - Perceived Value, Game Technology, Subjective Norm, Online Community Engagement, Mobile Game Loyalty, In-app Purchase Intention, Mobile Games.

\section{INTRODUCTION}

The game industry is growing nowadays. According to Global Games Market 2018, as released by (Seaver \& Kahler, 2018), around 2.3 billion gamers worldwide spent approximately 137.9 billion US dollars on the game in 2018. This number increased by $13.3 \%$ or 16.2 billion US dollars from the previous year. This positive trend is not only in the game industry but also in the mobile game industry. Indonesia is one of the world's most potential markets for mobile games. Indonesia was ranked 11th in terms of revenue from the mobile game of around 425 million US dollars (Allcorrectgames, 2017). According to Statista (2016), the number of mobile game players in Indonesia was 51 million players in 2016, and it was projected to reach 102.1 million players in 2021. Besides, the total revenue from this mobile game industry was predicted to increase from 425 million US dollars in 2017 to 1,152 million US dollars in 2021. Nevertheless, amidst the increase in the number of game players and revenue from the game industry, the market share of game developers from Indonesia was only $1 \%$, and the rest of 99\% was the market share of foreign developers (Anwari, 2017).
Besides, the market share of Indonesian game developers in 2015 declined from $1.2 \%$ to less than $1 \%$ (Wijman, 2017).

Most of the mobile game available in the market is the games which can be downloaded for free. In 2013, $90 \%$ of the games in the Apple app store can be downloaded at no cost (Hamari, Hanner, \& Koivisto, 2017). In the beginning, the mobile game developers depended on advertisements in the mobile game for their revenue (Kim, Kankanhalli, \& Lee, 2016); (C. C. Liu \& Chang, 2016). Subsequently, they created a feature, namely in-app purchase, which later became the primary revenue source in the mobile game (Hsiao \& Chen, 2016). The in- app purchase is a transaction to purchase a product or digital service in a particular application accessed through a cellular phone (C. L. Hsu \& Lin, 2016).

To persuade mobile game players to make transactions, many mobile game developers employ the "freemium" business model, enabling mobile game players to only access the primary feature of a game. They need to make payments to attain the game's full features (J. Liu, Kauffman, \& Ma, 2015). To maximize sales of in-app products and increase the market share of Indonesian developers in the mobile game, we need to explore the information about the market of the mobile game as well as the players of this mobile game. Payment intention is known as the predictor of purchase behavior, perceived value, and loyalty (C. L. Hsu \& Lin, 2015). (Hsiao \& Chen, 2016); (Lin, 2010) also supported this idea stating that the perceived value of having an internet-connected mobile device affects the intention to purchase cellular service.

It is imperative to maintain customer loyalty so that it can impact the main problem of this research. According to (Semeijn, van Riel, van Birgelen, \& Streukens, 2005), maintaining loyal customers will reduce the cost because a company needs to invest in seeking new customers. Also, this action will enable a company to increase its revenue. The loyal customers tend to purchase a product regularly, purchase the product in all product lines, recommend other people to purchase the same products, and not switch to competitors' products (Griffin, 2008); (Sarwar, Abbasi, \& Pervaiz, 2012). 


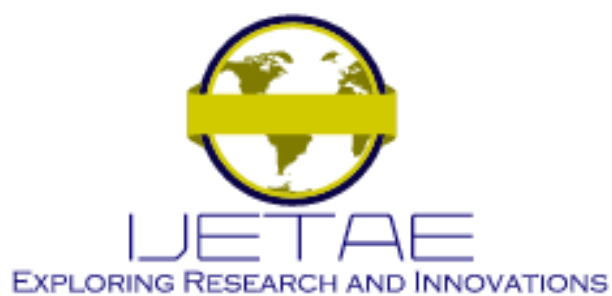

International Journal of Emerging Technology and Advanced Engineering

Website: www.ijetae.com (E-ISSN 2250-2459, Scopus Indexed, ISO 9001:2008 Certified Journal, Volume 11, Issue 09, September 2021)

Besides, (Rauyruen \& Miller, 2007) revealed that loyalty to B2B (business-to-business) service leads to future transactions.

Several researchers were conducted to explore the elements influencing game player loyalty (Merikivi, Tuunainen, \& Nguyen, 2017). (Balakrishnan \& Griffiths, 2018) discovered that game technology (game plot, game visuals, game duration, perceived ease of use, and online gaming services) had a substantial impact on game enjoyment and is important to determine the intent to play. Finally, it affects online game loyalty. Besides, Hsiao and Chen (2015) stated that perceived values of a game (playfulness, connectedness, access flexibility, and reward) directly affect the loyalty of mobile game players, but they have a minuscule effect on the intention to purchase in-app products among the non-paying players. Besides, the loyalty of mobile game players may affect in-app purchase intention. Based on those phenomena, we are interested in studying the effect of perceived values (playfulness, access flexibility, connectedness, game price, and reward), game technology, and social norm on the loyalty of mobile game players in Indonesia. Also, we try to investigate their effects on in-app purchase intention.

\section{LITERATURE REVIEW}

\section{Perceived Value}

Perceived value can be defined as the overall value given by customers to the utilization of product (goods or service), determined by their perception of the things they receive. This value can be increased by adding the given benefits or reducing the cost incurred by customers (Lovelock \& Wirtz, J., 2011). While (Kotler \& Amstrong, 2014) stated that perceived value is customer evaluation on the difference between all benefits and all costs of a company's product, compared to competitors' product.

This research utilizes the model of (Sweeneya \& Soutar, 2001), i.e., a modified model called PERVAL. This model assumes that the functional value comprises quality and price. Thus, PERVAL has several value measurements consisted of four dimensions, namely perceived value (emotional value, proxied by playfulness), social value (proxied by connectedness), value for the price (proxied by reasonable price and reward), and performance or quality (proxied by access flexibility) (Shiu, Walsh, \& Hassan, 2009).
(Park \& Lee, 2011) The traits of enjoyment, character competency, visual authority, and monetary values were discovered to be appropriate for describing how online game consumers perceive the value of game items. Using second request investigation, the coordinated advantage of collecting game items. The integrated value of purchasing game goods was calculated using second-order analysis (Gómez, Arranz, \& Cillán, 2006), (Keh \& Lee, 2006) stated that reward is a promotion tool to increase customer loyalty by offering an incentive to the customers who have cumulatively purchased a product. In terms of reward definition, this research refers to (Yi \& Joen, 2003), stating that reward is the benefit obtained when playing a mobile game.

H1: Perceived value has positive effects on game mobile loyalty.

H2: Perceived value has positive effects on In-Apps Purchase Intention

\section{Game Technology}

Quality of a product is one of the crucial factors affecting the consumption of customers (Zhao \& Fang, 2009). Since most of the activities of the online product are conducted via the internet, the quality of a product and service is the determining factor of customer behaviors (Boyer \& Hult, 2006), (Su, Chiang, James Lee, \& Chang, 2016).

According to (Zhao \& Fang, 2009), Technology Acceptance Model (TAM) is a model which can be used to adopt information and technology (IT). Based on this model, IT adoption of an individual can be affected by perceived usefulness and perceived ease of use. Perceived ease of use refers to what extent someone believes that using a particular system will provide easiness to him or her (Heijden, 2004). There are three indications of perceived ease of use (C.-L. Hsu \& Lu, 2007), ease of learning how to engage in an online game community, ease of becoming an expert while engaging in an online game community, and ease of participating in an online game community.

According to a model as proposed by (J. Wu \& Liu, 2007), (J. Wu, Li, \& Rao, 2008), there are five essential elements of the online game, namely, a game story, game graphic, game sound, game length, and game control. 


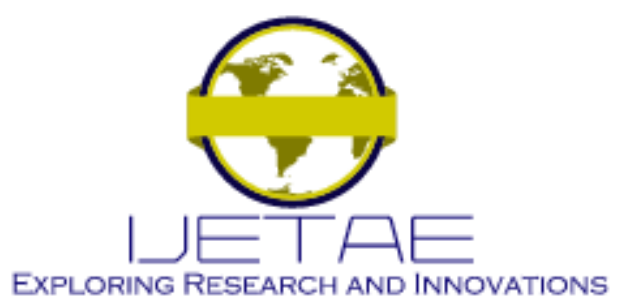

International Journal of Emerging Technology and Advanced Engineering

Website: www.ijetae.com (E-ISSN 2250-2459, Scopus Indexed, ISO 9001:2008 Certified Journal, Volume 11, Issue 09, September 2021)

This research uses the definition of the online game as proposed by (J. H. Wu, Wang, \& Tsai, 2010) with several modifications and adaptations. We selected a game story, game graphic, and perceived ease of use for the game technology variable proxies from the preliminary tests results.

H3: Game technology has positive effects on game mobile loyalty.

\section{Social Norm}

A social norm is a level by which someone feels that other people agree with their participation in a community of online games (C.-L. Hsu \& Lu, 2007). According to (Venkatesh, Morris, Davis, \& Davis, 2003), the social norm is a perception about whether somebody's friends will agree or not to his or her behavior. While (J. Wu et al., 2008), (Balakrishnan \& Griffiths, 2018) defined social norm as a level where someone views other people as the agreement of him or herself when using a particular application.

(Yee, 2007) showed ten sub-components of motivation that were organized into three broad components: accomplishment, social, and immersion. This research utilizes the definition of the social norm as proposed by $(\mathrm{C}$. L. Hsu \& Lin, 2016) mentioned earlier. The social norm indicators are 'the important people for me will agree if I use this application,' 'the important people for me think that I should use this application,' and 'the people who influence my behavior convince me to use this application.' By acknowledging self-motivation and external motivation from other people, someone will have an opportunity to be loyal.

H4: Perceived Value has positive effects on game mobile loyalty.

\section{Online Community Engagement}

Intensive interaction is currently supported by social media, information technology, and advanced communication tools. Technology provides a social media platform where online brand communities (OBCs) or brand pages have been created (Wirtz et al., 2013); (MartínezLópez, Anaya, Molinillo, Aguilar, \& Esteban-Millat, 2017). Since 2005, several researchers in the marketing field have a different opinion regarding 'engagement.' OBCs have also established 'engagement' or 'customer engagement' concepts.
Engagement refers to "an interactive experience between brand and customer, consisting of cognitive, emotional, and behavioral dimension which may have consequence based on the repetitive engagement process within a community or in its external environment" (Brodie, Hollebeek, Jurić, \& Ilić, 2011).

Several researchers have investigated engagement. Most marketers focus on social context and a brand's ability to communicate effectively to elicit a successful reaction and collective and creative experience (Gambetti, Graffigna, \& Biraghi, 2012); (Cheung, Shen, Lee, \& Chan, 2015). Besides, engagement is also a result of meaningful message delivery, which resonates with customers, energizes customers, and involves customers with a brand (Smith, 2016). Advertising Research Foundation (ARF) explained the process of mental activation engagement (ARF, 2006). Activation is the point at which engagement begins, and it is determined by the meaning produced by consumers as a result of the collaborative production process (ARF, 2006). Engagement is a process happening to respond to the communication, and it becomes the foundation of customer behavior (Maslowska, Malthouse, \& Collinger, 2016).

H5: Online community engagement has positive effects on game mobile loyalty.

Game Loyalty

Loyalty is the customer's tendency to repetitively purchase goods or services offered by a company (Anderson \& Srinivasan, 2003). Loyal customers will reduce business costs as a company does not need to spend more on acquiring new customers (Kleinaltenkamp, 2015). Besides, loyal customers tend to be unaffected by the cheap price offered by competitors, and they may invite other customers to purchase a company's product (Cavallone, 2017).

From those definitions, it is clear that mobile game loyalty tends to game players to purchase goods or virtual services regularly, purchase products in several product lines, refer a mobile game to other people, and not be interested in competitors' products. This research utilizes four indicators for measuring mobile game loyalty as proposed by (Yang \& Peterson, 2004). Hence, it can be summarized how loyal customers will make an extra effort to consume and deal with their preferred products. They may, in fact, purchase products in different product lines. 


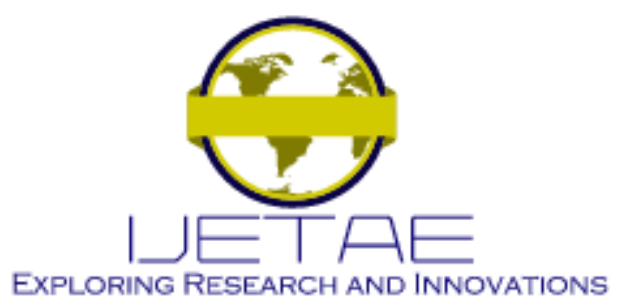

International Journal of Emerging Technology and Advanced Engineering

Website: www.ijetae.com (E-ISSN 2250-2459, Scopus Indexed, ISO 9001:2008 Certified Journal, Volume 11, Issue 09, September 2021)

H6: Perceived Value has positive effects on game mobile loyalty.

\section{In-Apps Application}

Purchase intention refers to a decision-making process that involves researching consumer motives for acquiring a product from certain brands (Shah et al., 2012). According to (Teng, Laroche, \& Zhu, 2007), defined purchase intention as a situation where customers tend to purchase a particular product in a particular situation. (Ghosh, 1990) stated that purchase intention is a useful tool to predict purchase process. Fundamentally, purchase intention may change, affected by price, quality, and perceived value. Also, customers are influenced by internal and external motivation during the purchase process (Gogoi, 2013).

According to (Griffin, 2008), when customers are purchasing a product, they will go through a purchase cycle consisting of several stages, namely, being aware of a product, making an initial purchase, evaluating that purchase, making the decision to repurchase, and lastly repurchasing (Hsiao \& Chen, 2016). This research utilizes four indicators for measuring in-app purchase intention (Hsu and Lin, 2016). These four indicators tend to repurchase in-app service, recommend other people to purchase in-app service, desire to purchase in-app service and repurchase the in-app service in the years to come.

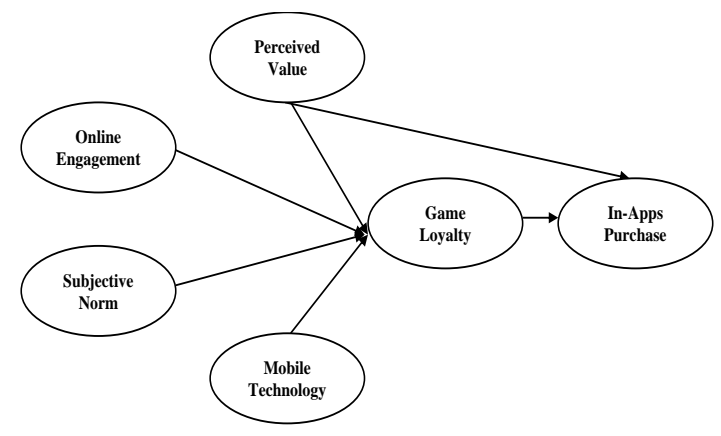

Figure1. Research Model

\section{RESEARCH METHODS}

This study employs a quantitative technique with a descriptive-associative research design. In addition. The population in this study are online mobile game players in Indonesia, the data collection method used a questionnaire distributed to 404 mobile game players in Indonesia with criteria who have made a purchase on their mobile game application, to determination of the sample, we are using a simple random sampling technique.
This research employs a survey method utilizing a questionnaire with a Likert scale. The data analysis technique used in this research is SEM-PLS using SmartPLS software version 3.0.

\section{RESUlt AND DiscUSSION}

\section{Measurement model}

Of the 404 respondents, $247(60 \%)$ are male, while the rest are female. Based on age criteria, 15 respondents (3.7\%) are less than 17 years old, 295 respondents $(73 \%)$ are 17-22 years old, 79 respondents (19.5\%) are 23-27 years old, 13 respondents $(3.2 \%)$ are $28-33$ years old, and two respondents $(0.5 \%)$ are more than 33 years old.

The SEM-PLS test consisted of two tests: the measurement model and the structural model. The measurement model was conducted using a validity and reliability test. In the validity tests, three indicators were found to be invalid, after we eliminate invalid indicators, then the next test results meet the validity qualification requirements, Whereas the composite reliability and Cronbach's alpha were used to evaluate the structural model we found that all indicators complied with reliability test. Figure 1 presents SEM analysis results.

Table 1.

Average and Composite Reliability Value

\begin{tabular}{|l|c|c|c|}
\hline \multicolumn{1}{|c|}{ Variable } & $\begin{array}{c}\text { Cronbach's } \\
\text { Alpha }\end{array}$ & $\begin{array}{c}\text { Composite } \\
\text { Reliability }\end{array}$ & (AVE) \\
\hline Game Loyalty & 0.872 & 0.907 & 0.662 \\
\hline In-app Purchase Intention & 0.920 & 0.943 & 0.806 \\
\hline Mobile Technology_ & 0.840 & 0.878 & 0.648 \\
\hline $\begin{array}{l}\text { Online Community } \\
\text { Engagement }\end{array}$ & 0.917 & 0.934 & 0.669 \\
\hline Perceived Value_ & 0.825 & 0.857 & 0.630 \\
\hline Subjective Norm & 0.892 & 0.933 & 0.822 \\
\hline
\end{tabular}

The further test was then conducted by omitting those three indicators, and we found that all indicators were valid and reliable. So, it allowed us to proceed to the next step, namely, the structural model. Before testing the overall model, we find out the magnitude of the influence of each relationship on the model through the coefficient determinant test ( $R$-Square Test) 


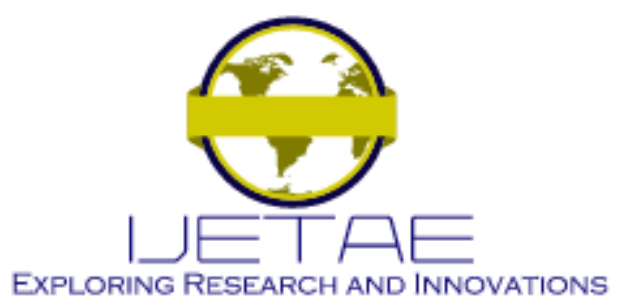

International Journal of Emerging Technology and Advanced Engineering

Website: www.ijetae.com (E-ISSN 2250-2459, Scopus Indexed, ISO 9001:2008 Certified Journal, Volume 11, Issue 09, September 2021)

Structure Model Test

Table 2.

R-Square Test

\begin{tabular}{|l|r|r|}
\hline & R Square & $\begin{array}{r}\text { R Square } \\
\text { Adjusted }\end{array}$ \\
\hline Game Loyalty & 0.480 & 0.475 \\
\hline In-app Purchase Intention & 0.267 & 0.263 \\
\hline
\end{tabular}

To interpret the results of data processing, we use RSquared Adjusted, because R-square Adjusted can provide a more specific view of that correlation via also deliberating how many impartial variables are brought to a selected version in opposition to which the model is measured. The R-Squared Adjusted value indicates the influence of independents variables (perceived value, game technology, social norm, and online community engagement) on the dependent variable (mobile game loyalty). The calculation result reveals that the r-squared value is 0.480 , indicating that $475 \%$ of the variance in mobile game loyalty could be explained by perceived value, game technology, and social norm. According to the findings, perceived value influences in-app purchase intention and mobile game loyalty by $26.3 \%$.

Table 3.

Structural Model Test

\begin{tabular}{|l|r|r|r|r|r|}
\hline & \multicolumn{1}{|c|}{$\begin{array}{c}\text { Original } \\
\text { Sample (0) }\end{array}$} & $\begin{array}{c}\text { Sample } \\
\text { Mean (M) }\end{array}$ & $\begin{array}{c}\text { Standard } \\
\text { Deviation } \\
\text { (STDEV) }\end{array}$ & $\begin{array}{c}\text { T } \\
\text { Statistics }\end{array}$ & P Values \\
\hline Game Loyalty >> In-app Purchase Intention & 0.245 & 0.241 & 0.055 & 4.461 & $\mathbf{0 . 0 0 0}$ \\
\hline Mobile Technology_-> Game Loyalty & 0.197 & 0.204 & 0.052 & 3.796 & $\mathbf{0 . 0 0 0}$ \\
\hline $\begin{array}{l}\text { Online Community Engagement -> Game } \\
\text { Loyalty }\end{array}$ & 0.092 & 0.092 & 0.044 & 2.090 & $\mathbf{0 . 0 3 7}$ \\
\hline Perceived Value_> Game Loyalty & 0.433 & 0.433 & 0.050 & 8.633 & $\mathbf{0 . 0 0 0}$ \\
\hline Perceived Value_> In-app Purchase Intention & 0.322 & 0.327 & 0.060 & 5.338 & $\mathbf{0 . 0 0 0}$ \\
\hline Subjective Norm -> Game Loyalty & 0.144 & 0.143 & 0.043 & 3.384 & $\mathbf{0 . 0 0 1}$ \\
\hline
\end{tabular}

The analysis result also shows that in all hypothesis testing's, the significance values were less than $0.05(5 \%)$, and the t-statistic values were larger than 1.96. These results explain that all these findings support the hypothesis of this research. It means, all exogenous variables, namely, perceived value, game technology, subjective norm, and online community engagement, affect loyalty. Besides, the result of this study indicates that loyalty affects in-app purchase intention. In terms of influence strength, perceived value affects game loyalty the most.
The result unveils that perceived value significantly affects mobile game loyalty. It is in line with Hsiao and Chen (2016), stating that the determinants of perceived value are playfulness, access flexibility, connectedness, and reward, significantly influencing mobile game loyalty. It indicates that the mobile game players in Indonesia are motivated to play and recommend a mobile game because they feel that this game offers emotional value (playfulness) and social value (connectedness)

The result of this research shows that game technology has a significant effect on mobile game loyalty. The result aligns with Zhao and Fang (2009), pointing out that game technology affects game enjoyment, which is the initial factor of online game loyalty. A pleasant game environment can also let the players freely create a story using the actors in the virtual world, and it can bring enjoyment as well as relieve the pain in the real world (Park \& Lee, 2011). Exciting graphics or animations are the keys to create an enjoyable experience in an online game because animations can increase enjoyment. Also, a distinctive action or pose, similar to the real world, has the same effect on increasing enjoyment (Hamari, 2015).

Another result of this research shows that social norm significantly affects mobile game loyalty. This correlates with (Zhao \& Fang, 2009), indicating how social norm significantly influences online game loyalty. It makes sense because intention can be affected by social norms and behavior (Ajzen \& Fishbein, 2000). (C.-L. Hsu \& Lu, 2007) also indicated that social influence, such as perceived critical mass, and social norm, affect the behavior as well as the intention to play online game players. Besides, (C. C. Liu \& Chang, 2016) reinforced the essence of continuous social interaction in an online game.

Lastly, online community engagement also significantly affects mobile game loyalty. This result is in line with (Fernandes \& Moreira, 2019). This notion validates customer brand engagement as the three-dimensions construct, which is stronger in its emotional side than its brand-functional relationship. Also, it shows the significant direct and indirect effect on brand loyalty. A mobile game player who interacts with other players can share and be more loyal to the game they play.

To increase the motivation of Indonesian Mobile Game players to make in-app purchases, Indonesian game developers must first form loyalty by applying perceived value as the most important, social norms as the second, and game technology as the last. 


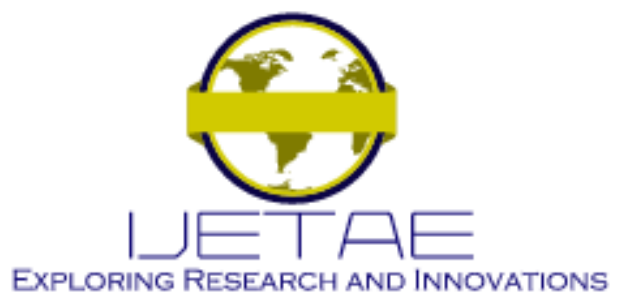

International Journal of Emerging Technology and Advanced Engineering

Website: www.ijetae.com (E-ISSN 2250-2459, Scopus Indexed, ISO 9001:2008 Certified Journal, Volume 11, Issue 09, September 2021)

Indonesian Mobile Game Developers can strengthen playfulness and also connectedness in Mobile Games by creating a leveling or quest system in the Mobile Game so that Mobile Game players feel more challenged and feel the excitement of the challenge. In addition, Indonesian Mobile Game developers can also create a guild feature in the Mobile Game so that Mobile Game players can feel the attachment between fellow Mobile Game players so that they tend to continue to play the Mobile Game if they want to interact with other Mobile Game players.

\section{CONCLUSION}

Referring to this research's research results and conclusions, we provide suggestions to the developers or game publishers in Indonesia as follows. First, to increase mobile game loyalty, developers of the mobile game in Indonesia should focus primarily on the perceived value, which will be offered to the mobile game players. Developers of the mobile game can optimize perceived value by maximizing efficiency and effectiveness to improve playfulness and connectedness in a mobile game and minimize the price offered to game players. Subsequently, developers of the mobile game in Indonesia can set social norms as the second priority and game technology as the last one, which should support the previous efforts.

To stimulate mobile game players to purchase in-app purchase services, developers of the mobile game in Indonesia should first establish loyalty by applying perceived value as the primary factor, followed by social norm as the second factor, and then game technology as the third one. Furthermore, developers of the mobile game in Indonesia should strengthen playfulness and connectedness by creating a leveling system or quest in a mobile game. Thus, the players will get more challenges and feel the excitement of these challenges.

\section{REFERENCES}

[1] Ajzen, I., \& Fishbein, M. (2000). Attitudes and the AttitudeBehavior Relation: Reasoned and Automatic Processes. European Review of Social Psychology, 11(1), 1-33. https://doi.org/10.1080/14792779943000116

[2] Allcorrectgames. (2017). 49 Mobile Games Markets. (Online). $\begin{array}{lllll}\text { Accessed } & 21 & \text { Mei } & 2018 & \text { from }\end{array}$ https://allcorrectgames.com/insights/mobile-game-market-index/

[3] Anderson, R. E., \& Srinivasan, S. S. (2003). E-Satisfaction and ELoyalty: A Contingency Framework. Psychology and Marketing, 20(2), 123-138. https://doi.org/10.1002/mar.10063
[4] Anwari, N. F. (2017). Indonesian Gamers' Data in 2017 - Consumer Insight. (Online). Accessed 21 Mei 2018 from https://www.gameprime.org/2017/09/the-indonesian-gamerconsumer-insight/

[5] Balakrishnan, J., \& Griffiths, M. D. (2018). Loyalty towards online games, gaming addiction, and purchase intention towards online mobile in-game features. Computers in Human Behavior, 87, 238246. https://doi.org/10.1016/j.chb.2018.06.002

[6] Boyer, K. K., \& Hult, G. T. M. (2006). Customer behavioral intentions for online purchases: An examination of fulfillment method and customer experience level. Journal of Operations Management, 24(2), 124-147. https://doi.org/10.1016/j.jom.2005.04.002

[7] Brodie, R. J., Hollebeek, L. D., Jurić, B., \& Ilić, A. (2011). Customer engagement: Conceptual domain, fundamental propositions, and implications for research. Journal of Service Research, 14(3), 252271. https://doi.org/10.1177/1094670511411703

[8] Cavallone, M. (2017). Marketing and Customer Loyalty: The Extra Step Approach. (A. Pastore, Ed.). Gewerbestrasse 11, 6330 Cham, Switzerland: Springer International Publishing AG. https://doi.org/10.1007/978-3-319-51991-3

[9] Cheung, C. M. K., Shen, X. L., Lee, Z. W. Y., \& Chan, T. K. H. (2015). Promoting sales of online games through customer engagement. Electronic Commerce Research and Applications, 14(4), 241-250. https://doi.org/10.1016/j.elerap.2015.03.001

[10] Fernandes, T., \& Moreira, M. (2019). Consumer brand engagement, satisfaction and brand loyalty: a comparative study between functional and emotional brand relationships. Journal of Product \& Brand Management, JPBM-08-2017-1545. https://doi.org/10.1108/JPBM-08-2017-1545

[11] Gambetti, R. C., Graffigna, G., \& Biraghi, S. (2012). The Grounded Theory Approach to Consumer-brand Engagement: The Practitioner's Standpoint. International Journal of Market Research, 54(5), 659-687. https://doi.org/10.2501/IJMR-54-5-659-687

[12] Gogoi, B. J. (2013). Study of Antecedents of Purchase Intention and its Effect on Brand Loyalty of Private Label Brand of Apparel. International Journal of Sales and Marketing Management Research and Development, 3(2), 73-86. Retrieved from http://www.tjprc.org/download.php?fname=2-33-1367497537-ABS Study of antecedents.pdf

[13] Gómez, B. G., Arranz, A. G., \& Cillán, J. G. (2006). The role of loyalty programs in behavioral and affective loyalty. Journal of $\begin{array}{lll}\text { Consumer } & \text { Marketing, 23(7), 387-396. }\end{array}$ https://doi.org/10.1108/07363760610712920

[14] Hamari, J. (2015). Why do people buy virtual goods? Attitude toward virtual good purchases versus game enjoyment. International Journal of Information Management, 35(3), 299-308. https://doi.org/10.1016/j.ijinfomgt.2015.01.007

[15] Hamari, J., Hanner, N., \& Koivisto, J. (2017). Service quality explains why people use freemium services but not if they go premium: An empirical study in free-to-play games. International Journal of Information Management, 37(1), 1449-1459. https://doi.org/10.1016/j.ijinfomgt.2016.09.004

[16] Heijden, H. van der. (2004). User Acceptance of Hedonic Information Systems. Mis Quarterly, 28(4), 695-704. 


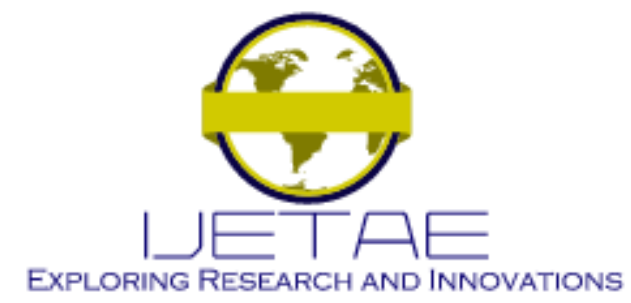

\section{International Journal of Emerging Technology and Advanced Engineering}

Website: www.ijetae.com (E-ISSN 2250-2459, Scopus Indexed, ISO 9001:2008 Certified Journal, Volume 11, Issue 09, September 2021)

[17] Hsiao, K. L., \& Chen, C. C. (2016). What drives in-app purchase intention for mobile games? An examination of perceived values and loyalty. Electronic Commerce Research and Applications, 16, 1829. https://doi.org/10.1016/j.elerap.2016.01.001

[18] Hsu, C.-L., \& Lu, H.-P. (2007). Consumer behavior in online game communities: A motivational factor perspective. Computers in Human Behavior, 23, 1642-1659. https://doi.org/10.1016/j.chb.2005.09.001

[19] Hsu, C. L., \& Lin, J. C. C. (2015). What drives purchase intention for paid mobile apps?-An expectation confirmation model with perceived value. Electronic Commerce Research and Applications, 14(1), 46-57. https://doi.org/10.1016/j.elerap.2014.11.003

[20] Hsu, C. L., \& Lin, J. C. C. (2016). Effect of perceived value and social influences on mobile app stickiness and in-app purchase intention. Technological Forecasting and Social Change, 108, 42-53. https://doi.org/10.1016/j.techfore.2016.04.012

[21] Keh, H. T., \& Lee, Y. H. (2006). Do reward programs build loyalty for services?. The moderating effect of satisfaction on type and timing of rewards. Journal of Retailing, 82(2), 127-136 https://doi.org/10.1016/j.jretai.2006.02.004

[22] Kim, H. W., Kankanhalli, A., \& Lee, H. L. (2016). Investigating decision factors in mobile application purchase: A mixed-methods approach. Information and Management (Vol. 53). Elsevier B.V. https://doi.org/10.1016/j.im.2016.02.011

[23] Kleinaltenkamp, M. (2015). Business Relationship Management and Marketing. https://doi.org/10.1007/978-3-662-43856-5

[24] Lin, C. P. (2010). Learning virtual community loyalty behavior from a perspective of social cognitive theory. International Journal of Human-Computer Interaction, 26(4), 345-360. https://doi.org/10.1080/10447310903575481

[25] Liu, C. C., \& Chang, I. C. (2016). Model of online game addiction: The role of computer-mediated communication motives. Telematics and Informatics, 33(4), 904-915. https://doi.org/10.1016/j.tele.2016.02.002

[26] Liu, J., Kauffman, R. J., \& Ma, D. (2015). Competition, cooperation, and regulation: Understanding the evolution of the mobile payments technology ecosystem. Electronic Commerce Research and Applications, 14(5), 372-391. https://doi.org/10.1016/j.elerap.2015.03.003

[27] Lv, Z., Halawani, A., Feng, S., Ur Réhman, S., \& Li, H. (2015). Touch-less interactive augmented reality game on vision-based wearable device. Personal and Ubiquitous Computing, 19(3), 551567. https://doi.org/10.1007/s00779-015-0844-1

[28] Martínez-López, F. J., Anaya, R., Molinillo, S., Aguilar, R., \& Esteban-Millat, I. (2017). Consumer engagement in an online brand community. Electronic Commerce Research and Applications, 23, 24-37. https://doi.org/10.1016/j.elerap.2017.04.002

[29] Maslowska, E., Malthouse, E. C., \& Collinger, T. (2016). The customer engagement ecosystem. Journal of Marketing Management, 32(5-6), 469-501. https://doi.org/10.1080/0267257X.2015.1134628

[30] Merikivi, J., Tuunainen, V., \& Nguyen, D. (2017). What makes continued mobile gaming enjoyable? Computers in Human Behavior, 68, 411-421. https://doi.org/10.1016/j.chb.2016.11.070
[31] Park, B. W., \& Lee, K. C. (2011). Exploring the value of purchasing online game items. Computers in Human Behavior, 27(6), 21782185. https://doi.org/10.1016/j.chb.2011.06.013

[32] Rauyruen, P., \& Miller, K. E. (2007). Relationship quality as a predictor of B2B customer loyalty. Journal of Business Research, 60, 21-31. https://doi.org/10.1016/j.jbusres.2005.11.006

[33] Sarwar, M. Z., Abbasi, K. S., \& Pervaiz, S. (2012). The Effect of Customer Trust on Customer Loyalty and Customer Retention: A Moderating Role of Cause Related Marketing. Global Journal of Management And Business, 12(6), 26-36.

[34] Seaver, R., \& Kahler, J. (2018). CORPORATE SPONSOR/ADVERTISER \& INDUSTRY REPORT, (February).

[35] Semeijn, J., van Riel, A. C. R., van Birgelen, M. J. H., \& Streukens, S. (2005). E-services and offline fulfilment: How e-loyalty is created. Managing Service Quality, 15(2), 182-194. https://doi.org/10.1108/09604520510585361

[36] Shah, S. S. H., Aziz, J., Jaffari, A. R., Waris, S., Ejaz, W., Fatima, M., \& Sherazi, S. K. (2012). The Impact of Brands on Consumer Purchase Intentions. Asian Journal of Business Management, 4(2), 105-110.

[37] Shiu, E. M. K., Walsh, G., \& Hassan, L. M. (2009). The consumer perceived value scale: replication, validation and development of a short scale. Journal of Retailing, 77(2), 203-220. Retrieved from http://strathprints.strath.ac.uk/15921/

[38] Smith, G. E. (2016). The Opt-Out Effect, Marketing Strategies that Empower Consumers and Win Consumer-Driven Brand Loyalty. (A. Neidlinger, Ed.). Old Tappan, New Jersey: Pearson Education, Inc. Old.

[39] Su, Y. S., Chiang, W. L., James Lee, C. T., \& Chang, H. C. (2016). The effect of flow experience on player loyalty in mobile game application. Computers in Human Behavior, 63, 240-248. https://doi.org/10.1016/j.chb.2016.05.049

[40] Sweeneya, J. C., \& Soutar, G. N. (2001). Fair Assured Services Without Any Special Support at the Core. Journal of Retailing, 77, 203-220. https://doi.org/10.1007/11753810_75

[41] Teng, L., Laroche, M., \& Zhu, H. (2007). The effects of multiple-ads and multiple-brands on consumer attitude and purchase behavior. Journal of Consumer Marketing, 24(1), 27-35. https://doi.org/10.1108/07363760710720966

[42] Venkatesh, V., Morris, M. G., Davis, G. B., \& Davis, F. D. (2003). Unusual formations of superoxo heptaoxomolybdates from peroxo molybdates. Inorganic Chemistry Communications, 27(3), 425-478. https://doi.org/10.1016/j.inoche.2016.03.015

[43] Wijman, T. (2018). Global Games Market 2018 Report. (Online). $\begin{array}{llll}\text { Accessed } & 23 & \text { Maret } & 2018\end{array}$ https://newzoo.com/insights/articles/global-games-market-reaches137-9-billion-in-2018-mobile-games-take-hal

[44] Wu, J. H., Wang, S. C., \& Tsai, H. H. (2010). Falling in love with online games: The uses and gratifications perspective. Computers in Human Behavior, 26(6), 1862-1871. https://doi.org/10.1016/j.chb.2010.07.033

[45] Wu, J., Li, P., \& Rao, S. (2008). Why They Enjoy Virtual Game Worlds? an Empirical Investigation. Journal of Electronic Commerce Research, 9(3), 219. 


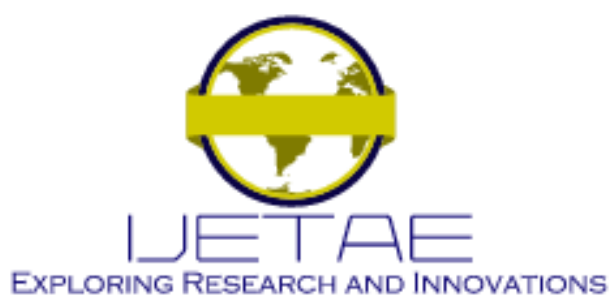

International Journal of Emerging Technology and Advanced Engineering

Website: www.ijetae.com (E-ISSN 2250-2459, Scopus Indexed, ISO 9001:2008 Certified Journal, Volume 11, Issue 09, September 2021)

[46] Wu, J., \& Liu, D. (2007). the Effects of Trust and Enjoyment on Intention To Play Online Games. Journal of Electronic Commerce Research, 8(2), 128-140.

[47] Yang, Z., \& Peterson, R. T. (2004). Customer perceived value, satisfaction, and loyalty: The role of switching costs. Psychology and Marketing, 21(10), 799-822. https://doi.org/10.1002/mar.20030

[48] Yee, N. (2007). Motivations for Play in Online Games. CyberPsychology \& Behavior, 9(6), 772-775. https://doi.org/10.1089/cpb.2006.9.772
[49] Yi, Y., \& Joen, H. (2003). Journal of the Academy of Marketing Science and Brand Loyalty. Journal of the Academy of Marketing Science, 31(3), https://doi.org/10.1177/0092070303253082

[50] Zhao, F., \& Fang, X. (2009). Factors affecting online game players' loyalty. Internationalization, Design, LNCS 5623, 197-206. https://doi.org/10.1007/978-3-642-02767-3_22 